\title{
大都市において銀行建築が構成する街並の物的属性について 街並の知覚構造に関する研究
}

\section{1. 研究の目的}

大都市の日常生活において，種々の建築的施設の果す 役割は非常に大きく，その拡充は都市政策の最も重要な 課題であることは論を待たない。特に近年になって建築 および建築群が都市の環境に重要な意味を持つことが注 目され，建築によって構成される都市空間の質的水準が 問われることとなった。このような時期に当たり公共的 建築施設のあり方を単独の都市施設として見るだけでは なく, 周辺街並の景観を構成する重要な構成要素として 位置づけ，その現状と可能性を検討することが重要であ ることから，筆者らが行った「大都市において学校施設 が構成する街並の物的属性について」は市は，市民にとっ て最も身近な公共施設である小学校を対象とし，その知 覚構造を周辺街並との関連において考察したものであ り，今後の良質な街並形成の可能性の視点から論ぜられ たものである。

本研究の目的は以上のような観点をさらに幅広く, 都 市を構成する各種の建築について展開するために，特に 中心商業地区における銀行建築のあり方に着目し，その 知覚構造を考察しようとするものである。

中心商業地区は都市において最も多様な活動が営まれ る地区であり，その活動を支えるために最も多様な要素 によって構成されていることはいうまでもない。このよ うな複雑な都市環境の中を来街者が行動する時, 来街者 は無限に近い情報の中から取捨選択し，自分の行動に必 要な情報のみを構造化し, 行動の指針としているに違い ない。筆者らは，このような仮定のもとに，中心地区空

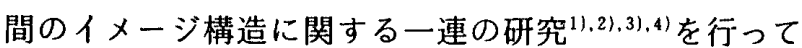
きた。

その中で（その 2$)$ において，中心地区空間を構成す る多様なエレメントが来街者によって想起される確率を 算定し，その想起確率を外的基準とする数量化一㥧によ る分析が行われた。エレメントの想起確率を説明する最

神奈川大学 教授. 工博

東京工業大学 教授・工博

䖵東京工業大学 助教授・工博 (昭和 61 年 7 月 11 日原稿受理)

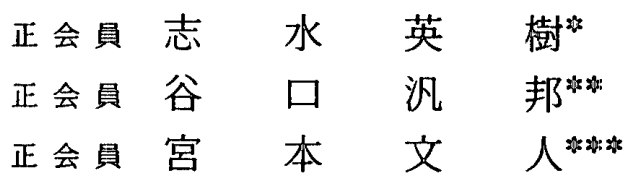

大の要因レンジは「エレメントの面積」であり，それに 次ぐものが「エレメントの業種」であった 種要因を構成するカテゴリーの中で「金融・不動産」は 最も低いカテゴリー値を示すことが確認され，次のよう に述べられている。「地区のく図一地>体制において 〈図＞となるべき物理的条件を十分満たしていな がら，最も低いポテンシャルを示しているのが「金融・ 不動産」である。面積が大きく，同業者が少なく，その 上に地区の一等地を占めることが多いこの業種が，地区 のく図>として機能しないばかりかく地>の連続性を “裁断”してしまうとすれば，その配置計画上，あるい は建築設計上多くの配慮が必要となってくるだろう」。 もちろん「金融・不動産」のカテゴリー值が低いにもか かわらず，各地区の都市銀行支店は常にその地区の枢要 の地点に立地し, 地区のイメージ構造に深く関与してい る。

本論文は,このような銀行建築とその周辺の街並との 知覚的関係性を探るための第一段階として, 被験者がよ゙ のような物理的属性を基準として知覚しているかを考察 しようとするものである。さらに本論文の続編において, 知覚次元として抽出された物理的属性が, 銀行や街並に 対する情緒的な評価構造とよ゙のように関連するかを考察 するために，SD 法を適用することとしている世”。

\section{2. 研究の意䓵}

銀行建築を軸として, 街並の景観構造を考察すること は以下の諸点で意義あるものと思われる。

（1）前述したように，銀行建築は，広大な都市空間 の中において特に中心性の高い地区に立地することが通 例であり, その地区の中でも特に枢要な地点に立地して いることが多い。したがって, 銀行建築のあり方が, 周 辺の街並の知覚構造に対して大きな影響力を保持してい ると推定される。

（2）通常の商業地域において, 銀行建築は郡辺の一 般商店よりも，建築材料やデザインの水準において一段 上位にある場合が多い。しかし一方, 来街者で最も賑わ う休日や, 平日の午後は閉店し, シャッターを下ろして しまう。このような銀行建築と周辺街並との関係性を知 
覚構造の側面から考察することは，今後の商業空間の街 ゔくりや景観構造を考える上で有益な基礎的知見を提供 するものと思われる。

（3）銀行建築の計画と設計は，銀行本部によって統 括的に遂行されるため，もし有益な知見が得られれば， 有効に利用される可能性がある。

（4）金融自由化やキャッシュカード化に伴い，銀行 建築のあり方も今後大きく変化し, 従来の閉鎖的建築か ら，より開かれたコミュニティバンク ${ }^{15)}$ として準公共的 な役割が期待されている。

\section{3. 実倹の概要}

実験は銀行を中心として撮影された葉書大のカラー写 真 80 枚を，20名の被験者に示し，4段階に分類させる という方法である。

\section{3-1 調査対象の撮影}

調查対象とした銀行は，東横線，新玉川線，田園都市 線，大井町線，目蒲線，池上線，小田急線（参宮橋上り 町田まで）の各鉄道沿線の駅前地区に存在するものであ る。これら鉄道沿線はいずれも東京の城南部にあって， 都心性の高い地区から郊外の新興住宅地区に至るまで, 多様な住宅地区や住工混合地区を背景とする駅前商業地 区を形成している。これらの沿線における 92 の鉄道駅 を中心とする地区に存在する 217 の銀行建築を調査対象 とし，約 480 枚の写真を撮影した。

撮影方法は次のような規準をできるだけ遵守して行 い，より客観的な分類が可能となるよう配慮した。

（1）撮影の対象は，○○銀行と名のつくものすべて であり，その他の○○信用金庫や○○組合といった金融 機関は対象外としている。

（2）使用レンズはすべて $28 \mathrm{~mm}$ である。

（3）対象となる銀行自身の性格とその周辺街並みの 状況が明確に写るよう，原則として，銀行のファサード 部分が全画面の $1 / 6$ 程度となるように撮影距離を定め た。

（4）撮影のアングルは，原則として，道路の反対側 から，銀行の両隣り部分を含み，しかも，道路の両側の 街並が読み取れるように定めた。(図一1)

（5）撮影日は，昭和 61 年 4 月 2 日〜 4 月 14 日の平 日であり，晴天または曇天の日である。撮影時間は，銀 行の開店時間と街路の交通量を考慮して, 10：00〜15：

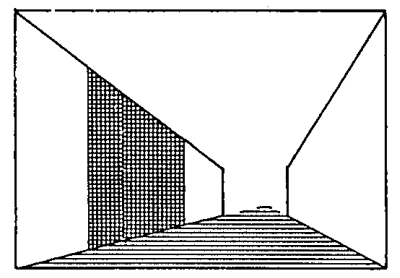

非角地

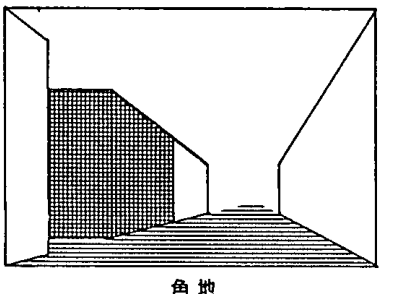

角地 図-1＼cjkstart写真撮影の典型アングル
00 とした。

\section{3-2 実験用の写真の選択}

（1） 写真撮影に関する諸原則も,全面道路の広さや, 角地の立地状況等によって必ずしも正確には遵守できな い場合があったが, 実験用の 80 枚の写真の選定に当たっ ては, 可能な限り，この原則に沿ったものから選択した。

（2）銀行建築自体の持つ多様な物理的属性（例えば 色彩，テクスチャー，ファサードの形態，立地条件等） をできるだけ網羅するように配虑しながら，一つの特性 を示す事例の数が偏在しないよう選択した。

（3）銀行周辺の街並の状況についても可能な限り多 様な属性（例えば, 全面道路の状況, 周辺の土地利用, 建築密度, 交通量等) を網羅するよう配慮し，しかも， 特定の属性に偏在しないように選択した。

（4）銀行と周辺街並の関連性については，建物自体 の多様性と，周辺街並の多様性の組み合わせによって， できるだけ多様な関連性を網羅するよう配慮した。

（5）以上のようにして選定された 80 枚のカラー写 真は葉書大 $(147 \mathrm{~mm} \times 100 \mathrm{~mm})$ に引伸ばされて実験用 とされた。(写真一1)

\section{3-3 実験の方法}

（1）選定された 80 枚の写真は 20 人の被験者によっ て，3 種類の実験 A，B，Cについて，それぞれ 4 段階 の作業により分類されたせ2)。

実験 $\mathrm{A} ， \mathrm{~B} ， \mathrm{C}$ および，4 段階の分類の教示内容につ いては（表一1）のとおりである。

\section{表一1＼cjkstart実験別の分類作業のための教示内容}

実皟A・银行建祭についての分類

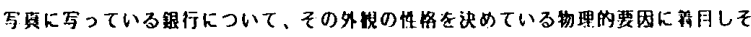
の要因にしたがって、ます全体をら分期(サ1)して下さい。 たくし、悢行の周边の貝眼については、全く考度しないで下さい。

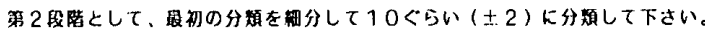

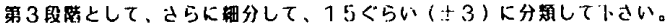

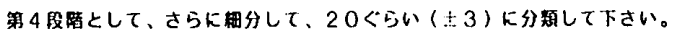

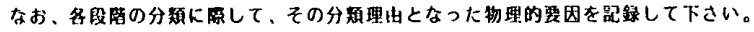

実略B・周这影並についての分類

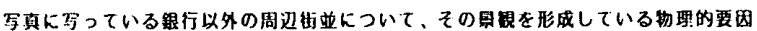
に着目し、その要因にしたがって、まず全体を5分頪（士1）して下さい。

だし、银行自身の外睤については、全く考慮しないで下゙さい。

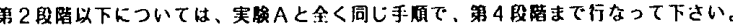

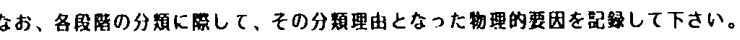

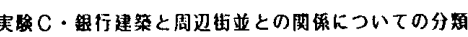

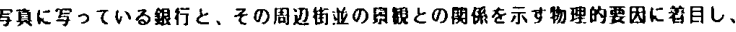
その要团にしたがって、ます全体を5分頑(士1)して下さい。

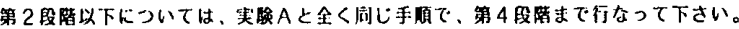

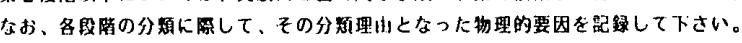

その他の注意事項

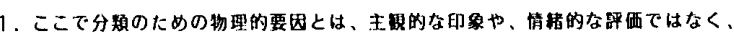
対象の何らかの物理的特梅であり、それを基第として分類して下さい。

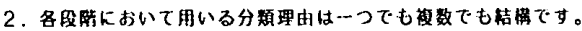

3. 分桷理由は、分斯しやすいものから䐓次用いて下さい。 


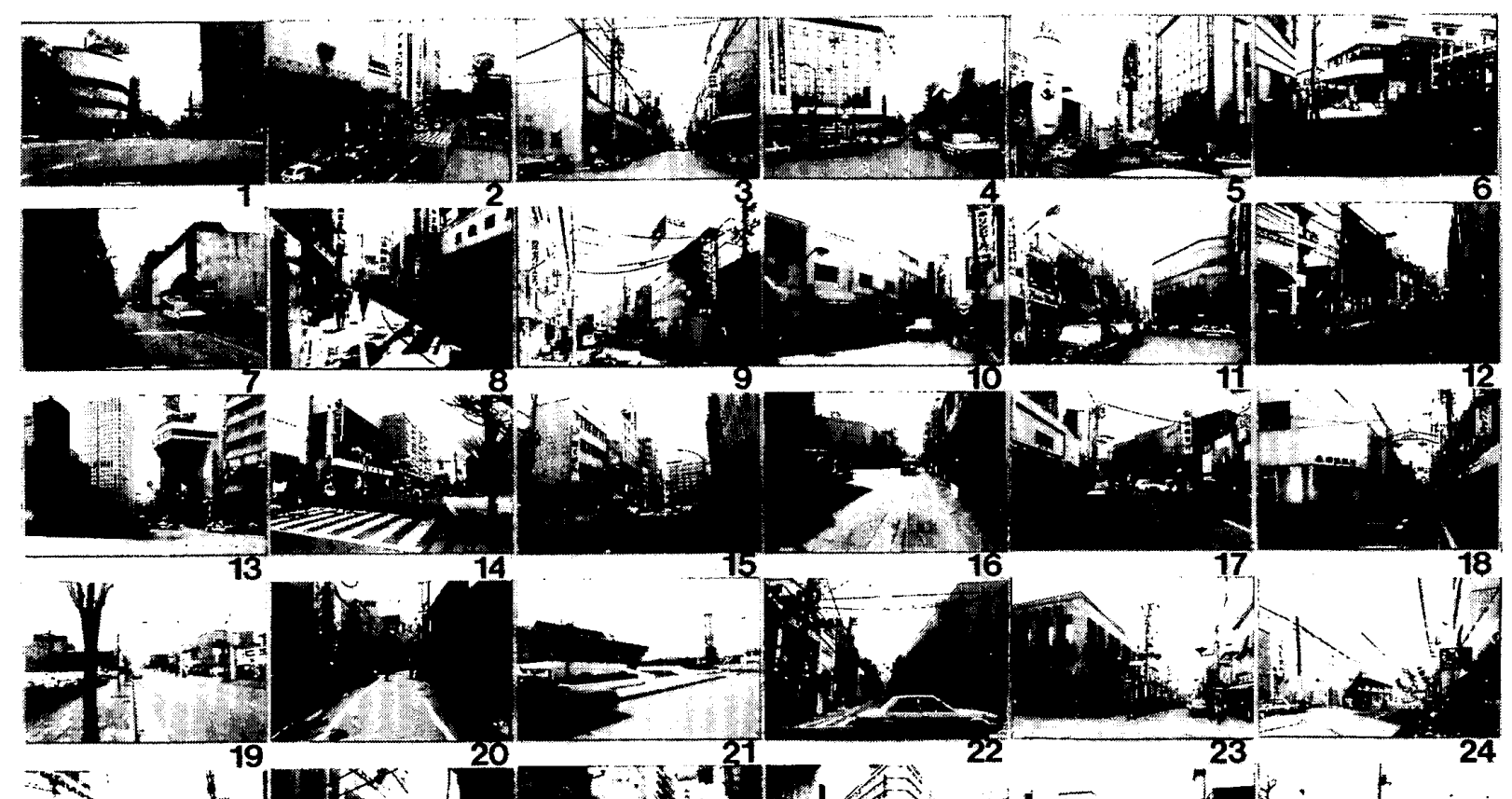

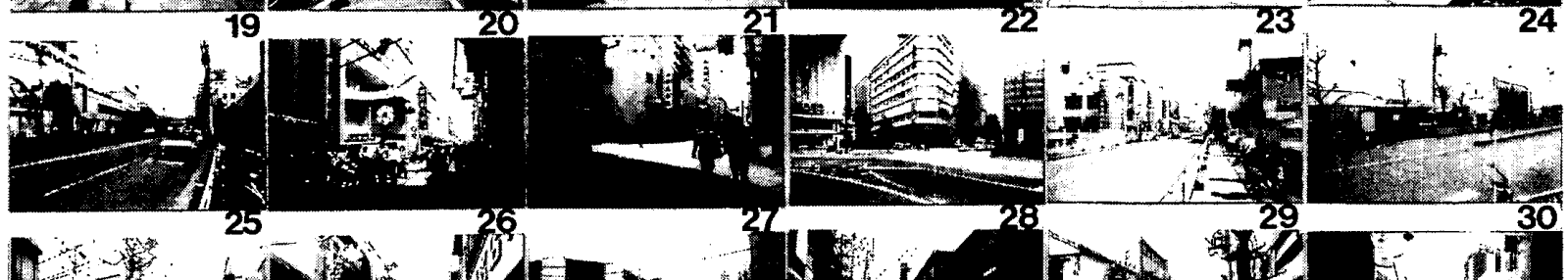

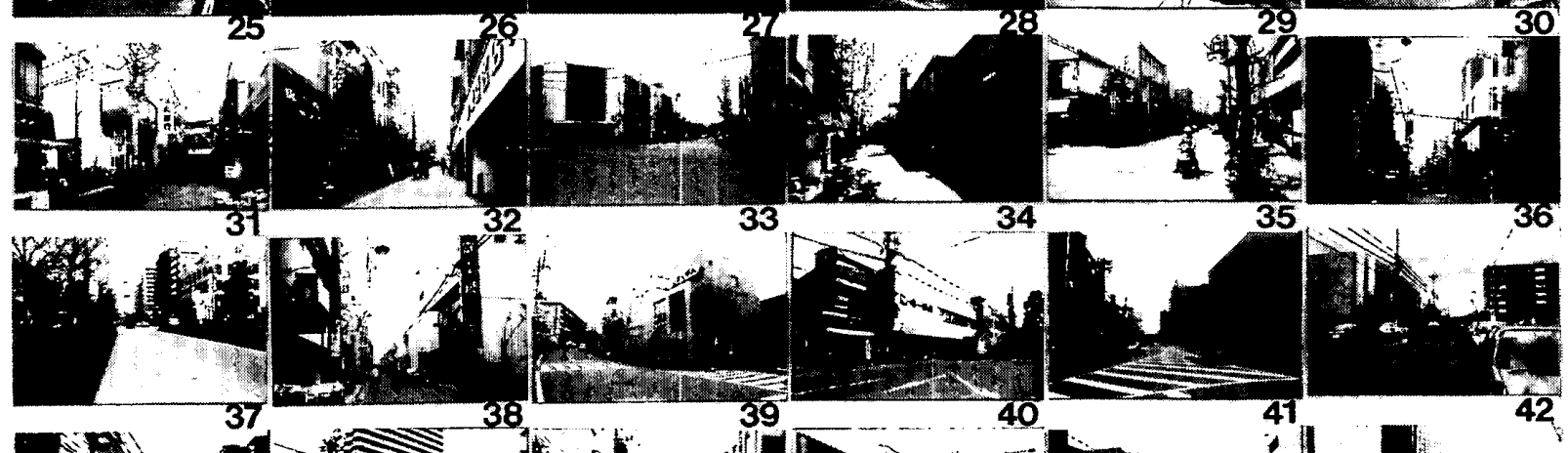

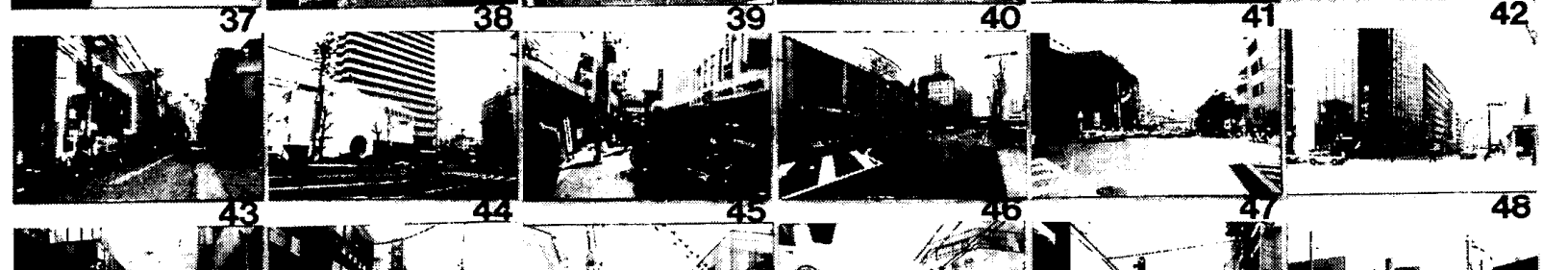

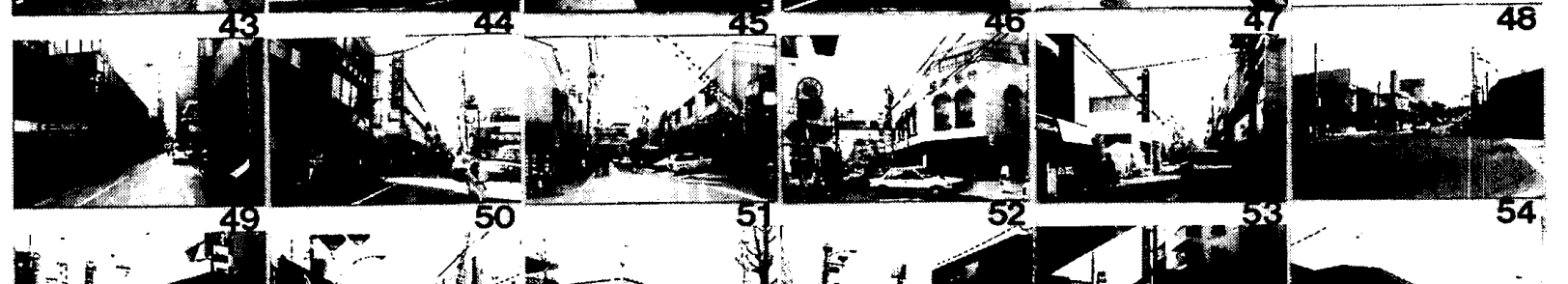

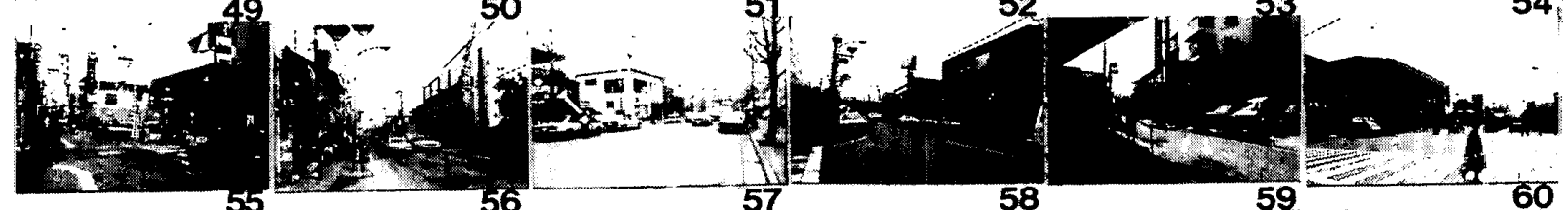
1. I I

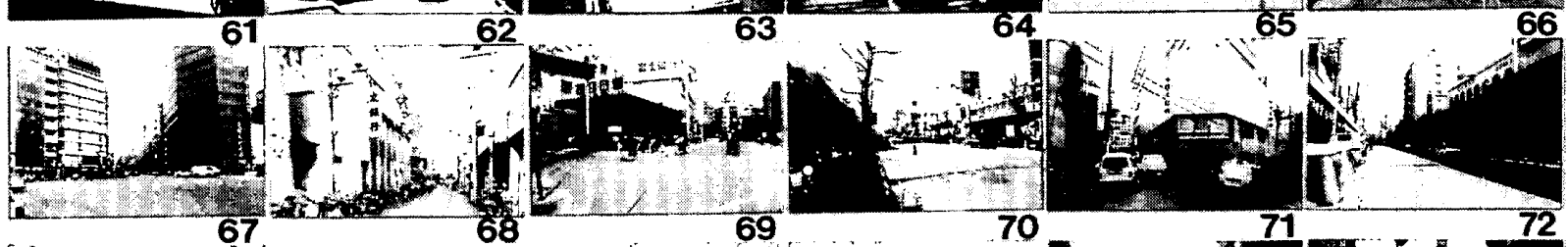

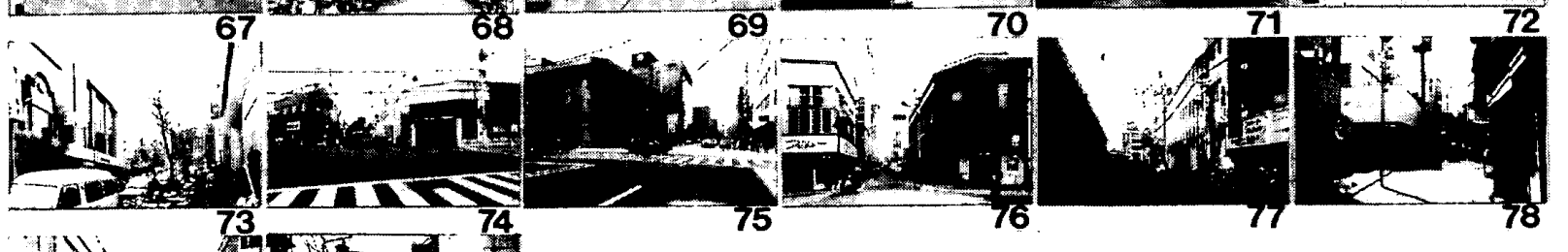
14. 
（2）実験 A，B，Cの各段階ごとに, 分類理由を記 録させた。

なお，分類理由の指摘方法は，あらかじめ用意された 分類理由の中から指摘するのではなく, 被験者が自由に 指摘する方法であり，また，各段階において使用する分 類理由の数も自由である。

（3）被験者は, 神奈川大学建築学科大学院 1 年生 ( 4 人内女性 1 人) および, 学部 4 年生 (16 人内女性 2 人), 合計 20 人である。被験者を建築学科学生に限ったのは, 対象を単なる印象による分類ではなく，物理的要素を設 定して分類するという作業が，一般の被験者にとっては 相当に困難な課題であることが， 2 人の被験者によるパ イロット実験によって確かめられたからである。

\section{4. 分類理由として用いられた物的属性}

20 名の被験者による 4 段階の分類作業が行われた過 程において, 分類理由として用いられた物的属性の頻度 を分類段階別に整理したのが（表一2）である。

被験者があげた分類理由の表現のための言葉が違って も，その意味が類似の場合は一つにまとめられている。 分類理由の集計方法は，同一被験者が同一段階に用いた 分類理由を加算したものであるが，同一被験者が同一段 階で,同一分類理由を複数回用いた場合は 1 としている。 したがって, 同一欄内の数字は, 被験者数 (20) を越え

\section{表一2 実験別の分類理由}

\begin{tabular}{|c|c|c|c|c|c|c|c|}
\hline & & 分 類 理 由 & 段落 1 & 2 & 3 & 4 & 合 \\
\hline & & 包色昣とテクスチャー & 15 & 13 & 16 & 12 & 56 \\
\hline & 7 & 建物の高さ & 5 & 4 & 3 & 3 & 15 \\
\hline 実 & $\boldsymbol{P}$ & ファサードの凹凸甠 & 6 & 10 & 9 & 9 & 34 \\
\hline & サ & 雭の形䍐 & 5 & 7 & 9 & 8 & 29 \\
\hline R & 1 & 柱型の形露 & 2 & 4 & 3 & 4 & 13 \\
\hline & ドの & 出入口の城麻 & 2 & 2 & 5 & 0 & 9 \\
\hline A & 形 & 至根の形息 & 7 & 6 & 2 & 3 & 18 \\
\hline & 謈 & 时国场の形整 & 0 & 1 & 2 & 2 & 5 \\
\hline & & 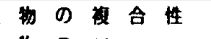 & 5 & 2 & 3 & 0 & 10 \\
\hline & & 物 の 新しさ & 5 & 7 & 5 & 6 & 23 \\
\hline
\end{tabular}

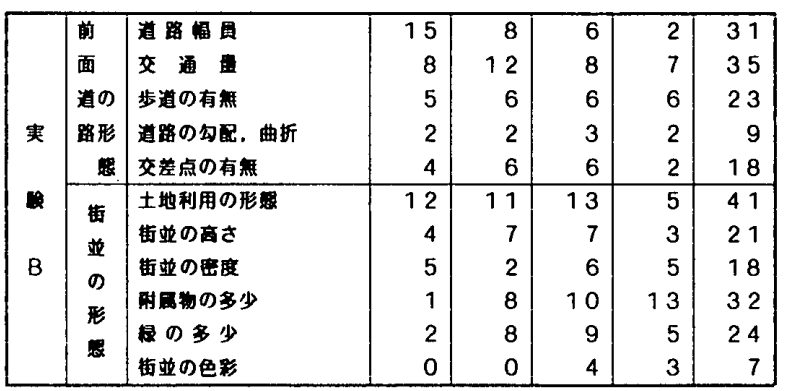

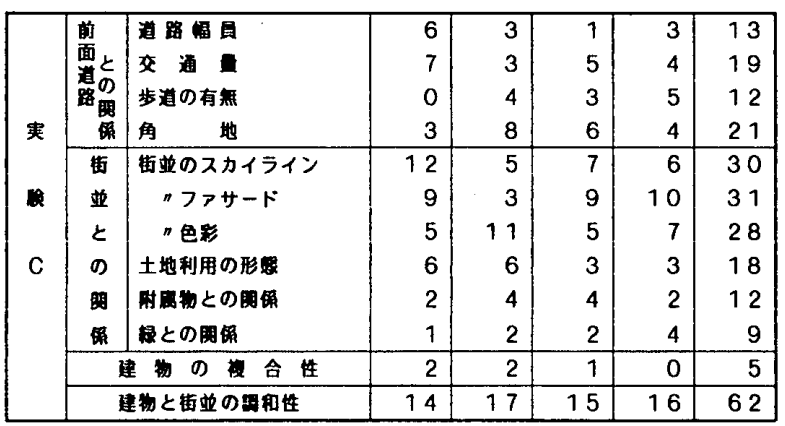

ることはない。

なお，この分類理由の集計は, 後述する多次元尺度構 成法において抽出される分類軸の解釈をより正確にし， また容易にするために準備的にまとめられたものであ る。

（1）実験 $\mathrm{A}$ の銀行建築自体に関する分類理由は，壁 面の色彩とテスクチャーが最も高頻度に用いられ，ファ サードの凹凸性, 窓の形態, 建物の新しさ等が続いてい る。しかし, 分類作業の段階別には明確な特徵が出てい ない。

なお，分類理由としてあげられた壁面の色彩とテクス チャーについては，例えば「煉瓦の壁面」や「カーテン ウォール」のように色彩かテクスチャーか判然としない ものが多く，しかも，それらの間に強い関連性があるた め, 一つの分類理由としてまとめられている。また, 建 物の新旧についても, 建物が物理的に新しいものと, そ のデザインの斬新性とが判然としない場合があり, しか も両者の間に強い関連性があるため, やはり一つの分類 理由としてまとめられている。

( 2 ) 実験 Bの周辺街並に関する分類理由は頻度順に, 土地利用形態, 前面道路の交通量や幅員, 二次的附属物

(看板や電柱等) の多少等であるが, 分類作業の段階別 には, 前面道路の幅員が初期段階に多く, 二次的附属物 の多少は後期の段階に多い。

（3）実験Cの銀行建物と周辺街並の関係性に関する 分類理由は, 街並のスカイライン, 街並のファサード, 街並の色彩等の関係性が高く, 角地性がそれに続いてい る。しかし，最下段の「建物と街並の調和性」に関する 分類は特定の物的属性を伴わず，総合的印象として出て きたものを，一括してまとめたものである。分類段階別 に見ると, 街並のスカイラインや, 道路幅員等が初期に 多く, 街並のファサードが後期に多い。

\section{5. 分類過程における物的属性}

実験 A，B，Cのそれぞれにおいて，80 枚の写真が 分類される過程を把握するために，クラスター分析 (Johnson の HICLUST ${ }^{\ddagger 3}$ ) ) が行われ, 階層別の分類 理由として用いられた物的属性との対応関係が（表一3） に示されている。なお, 入力デー夕は各被験者の類似性 行列の平均值である。

（表一1）の実験の教示内容で示したように，本実験は 被験者に 4 段階の分類作業をさせている。この分類作業 の過程で, 事例 I とJが L段階まで同一グループにある 場合,

I と J の類似度 $S_{i j}=N_{L} / N_{L M}$

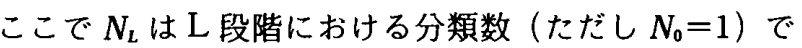
あり， $N_{L M}$ は最終段階（ここでは第 4 段階）の最大分類 数である。

入力データとしての 20 の個人別類似性行列をここに 
表一ーA クラスター分析と分類理由

\begin{tabular}{|l|l|l|l|l|l|l|l|l|l|l|l|}
\hline & \\
\hline
\end{tabular}

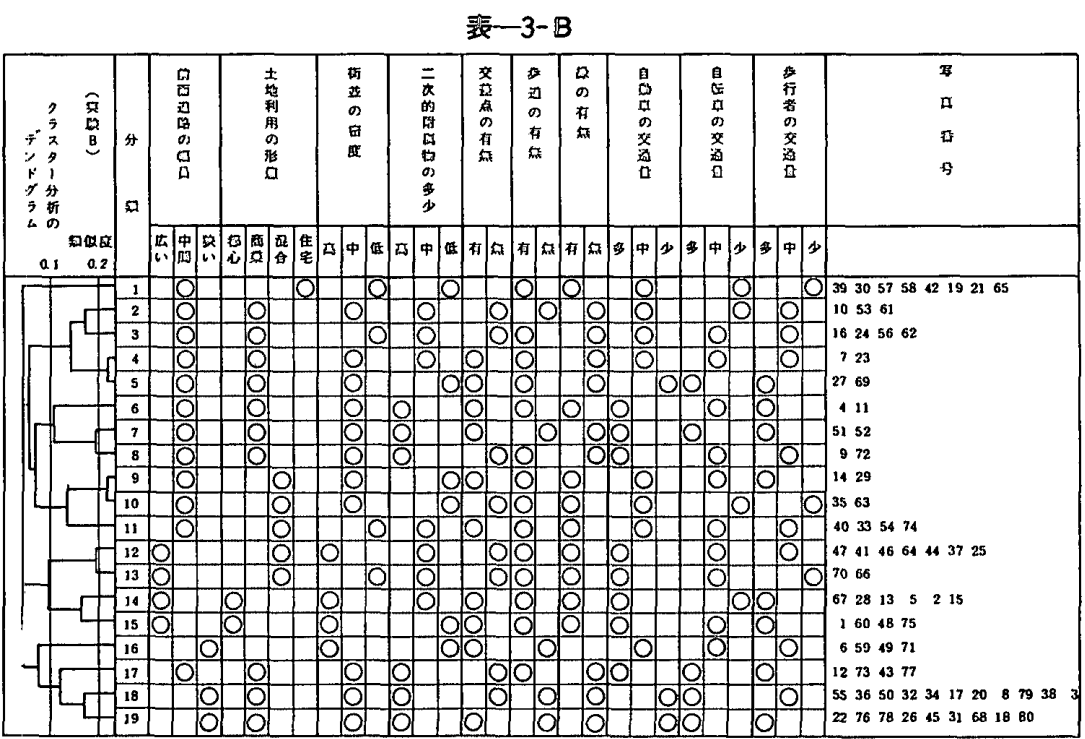

表一4 実跧による個人別集計と類似性 行列の一例（被鏂者 01）

\begin{tabular}{|c|c|c|c|c|}
\hline \multicolumn{2}{|c|}{ 段 } & \multicolumn{2}{|c|}{ 陌 } & \multirow[b]{2}{*}{ 真 惩 易 } \\
\hline 1 & 2 & 3 & 1 & \\
\hline 1 & 1 & 1 & 1 & $21,57,65$ \\
\hline \multirow[t]{2}{*}{2} & 2 & 2 & 2 & 17 \\
\hline & & & 3 & $1,7,16,18,10,11,71$ \\
\hline \multirow[t]{6}{*}{3} & 3 & 3 & 4 & 53,56 \\
\hline & & & 5 & 16,79 \\
\hline & 4 & 4 & 6 & $24,37,45,50,61,74$ \\
\hline & & & 7 & $3,11,12,15,6 i$ \\
\hline & 5 & 5 & 8 & $14,32,33,35,70,77$ \\
\hline & & & 9 & $30,47,19,62$ \\
\hline$\cdots$ & $\cdots$. & $\cdots$ & $\cdots$ & $\ldots$ \\
\hline$\cdots$ & $\because$ & $\ldots$ & $\ldots$ & \\
\hline 6 & 11 & 15 & 22 & $28,48,67$ \\
\hline & & 16 & 23 & $2,4,5,13$ \\
\hline
\end{tabular}

凡例

被䮖者O1の場合、第一段階のE

分頑に始まり、第 4 段階の 23 分

類に経わるこしを示している。

\begin{tabular}{|c|c|c|c|c|c|c|c|c|}
\hline & & $\frac{\Lambda}{2}$ & $\frac{5 !}{3}$ & $\frac{11}{4}$ & $\frac{14}{\ldots}$ & & & \\
\hline 2 & 43 & & - & - & $\ldots$ & $\cdots$ & - & $=-$ \\
\hline 3 & 43 & 43 & - & - & $\cdots$ & $\cdots-$ & - & - \\
\hline 4 & 43 & 999 & 43 & - & $\cdots$ & $\cdots-$ & - & -- \\
\hline 5 & 43 & 999 & 43 & 999 & $\ldots$ & & & \\
\hline & & $\ddot{13}$ & $\ddot{13}$ & 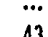 & $\ldots$ & & - & $\cdots$ \\
\hline 40 & 999 & 43 & ... & 4. & $\ldots$ & & & \\
\hline 78 & 43 & 43 & 43 & 43 & $\ldots$ & & $\ldots$ & - \\
\hline 79 & 43 & 13 & 261 & 43 & $\ldots$ & & 13 & - \\
\hline 80 & 43 & 43 & 43 & 43 & $\ldots$ & $\ldots 26$ & $61 \quad 4:$ & 3 \\
\hline
\end{tabular}

几例

被龭者○10境合、写其 3 と写县 79 は 第一段階まで同ーグルーフにあったので 粼似度は、 $6 / 23=0.261$ となる 上䘚における数値け、頍似度を 1000 佫したものであるが、999は1000 を示す。

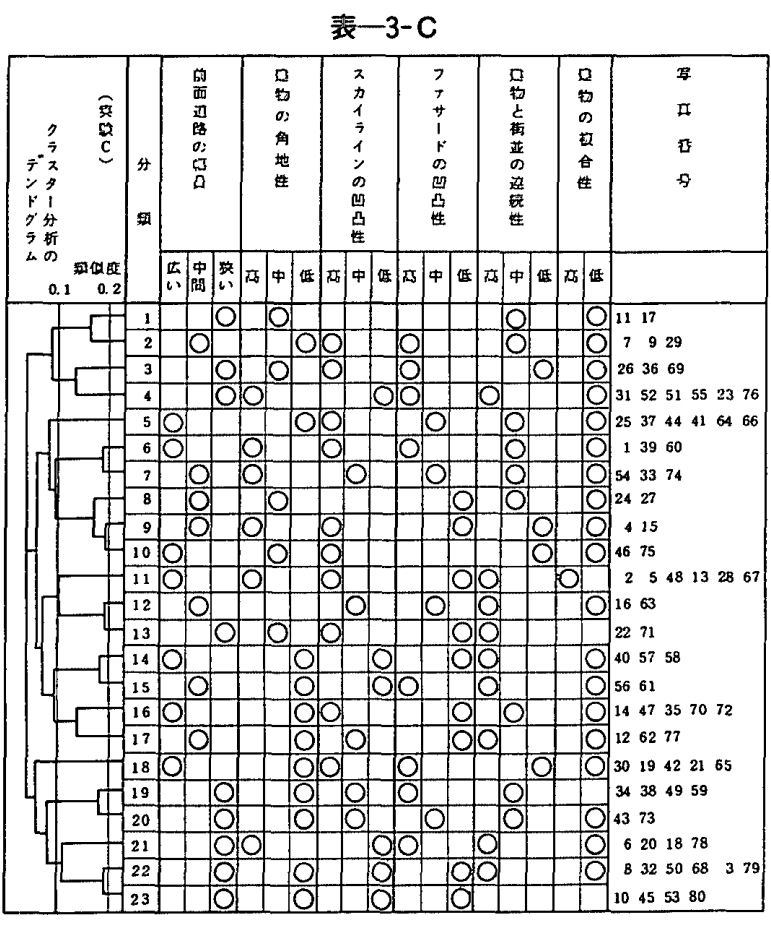

示すことは不可能である。すなわち，80×80 の対角要 素を除いた三角行列を 20 個示すことが必要となる。そ こで，その一部を例示したものが表一4である。

表一3の○印は, 各クラスターに分類された写真番号 のうち、分頪理由として考えられる物理的属性のいずれ かに $2 / 3$ 以上含まれる時つけられている。いずれの属性 にも片寄っていない時，すなわちその分類理由が有効に 動いていない場合は無印となっている。

（1）実験 $\mathrm{A}$ の銀行建築の分類過程を見ると，まず壁 面色彩が茶色系から白色系へと分類され，続いてガラス 壁面の大小によって分類されている。これらの 2 段階の 分類により, 銀行建築は, 茶色系の壁, カーテンウォー ルの壁, 白色系の壁の 3 種類の壁面によってまず分類さ れることがわかる。

さらに, 出入口の位置, ファサードの凹凸性, 建物の 新しさ等が分類基準として用いられ細分されている。

これらの属性に比較して, 空の形態, 柱型の有無, 屋 
根のこう配, 建物の複合性等は, 極めて局部的な分類に 対してのみ作用していることがわかる。

（2）実験 Bにおける銀行建築の周辺街並の分類過程 を見ると，まず前面道路の幅員によって分類され，続い て周辺の土地利用形態によって, 合計 4 つの大分類に分 類されている。さらに, 道路両側の街並の密度, 街並の 二次的附属物の多少, 交差点の有無, 歩道の有無, 緑の 有無, 自動車・自転車・歩行者の交通量等によって細分 されている。これらの中で, 緑の有無は土地利用の形態 との相関, 自転車・歩行者の交通量は二次的附属物の多 少との相関が梕められる。

（3）実験Cにおける銀行建築と周辺街並との関係性 に対する分類過程を見ると，まず前面道路の幅員によっ て大分類され，続いて建物の角地性によって分類されて
いる。さらに, 街並のスカイラインの凹凸性, 街並のファ サードの凹凸性, 建物之街並の連続性, 建物の複合性等 によって分類されていることを見ることができる。しか し，建物の複合性に関しては局部的な分類にとどまり， しかも, 大分類から細分類への過程は, 実験 A・Bに 比して，やゃ不明瞭である。

\section{6. 分類軸の抽出}

実験 A，B，Cにおいて，被験者によって行われた分 類過程が前節のクラスター分析によって抽出された。本 節では，このような分類過程において知覚された物的属

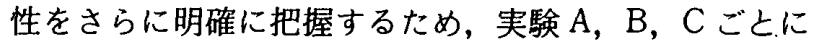
多次元尺度構成法 SINDSCAL ${ }^{(4)}$ による分析を行い, 分 類軸を抽出した。

本節で使用した SINDSCAL は二相三元の多次元尺

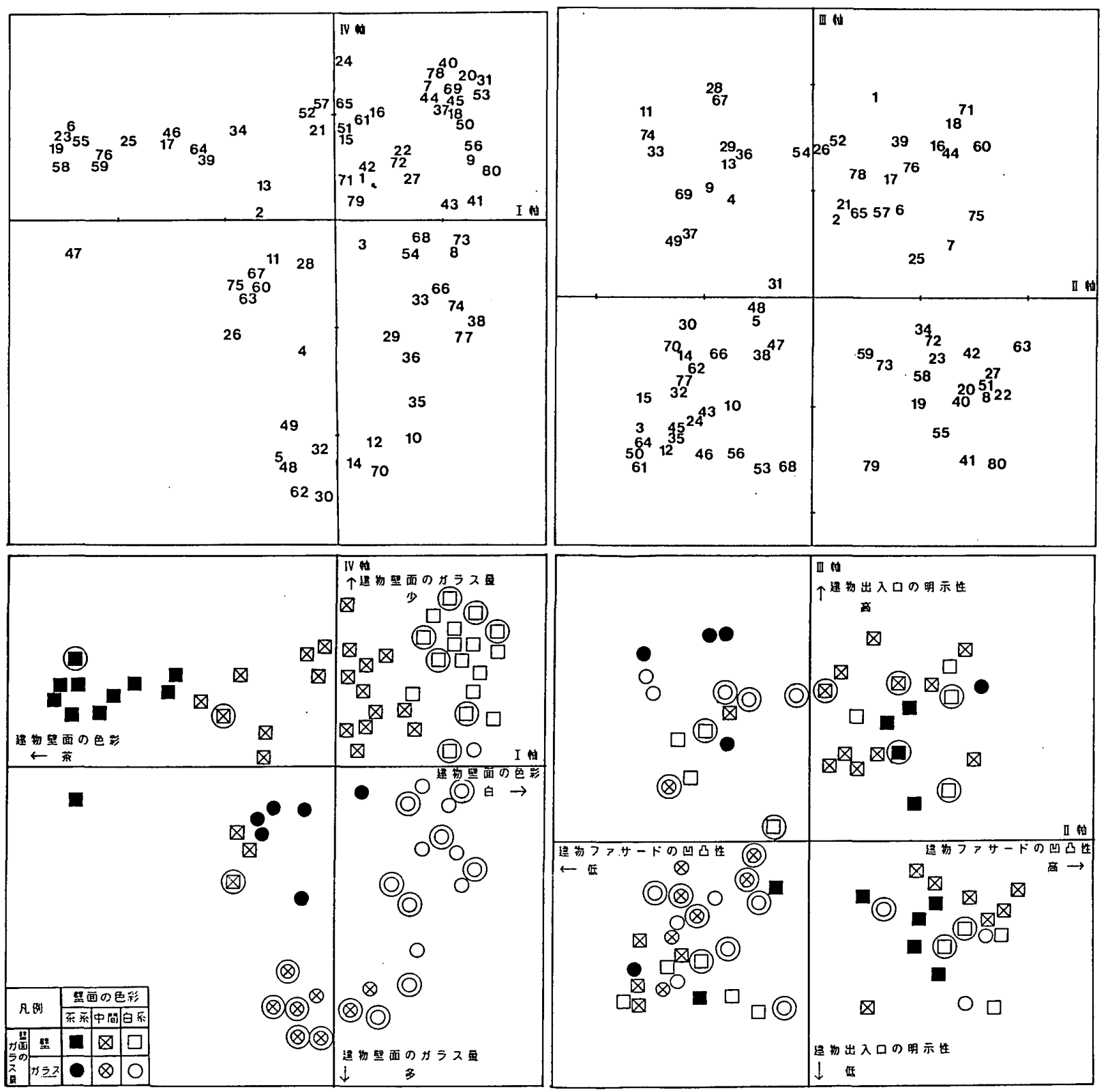

※ 図中の大きな○印はく建物の新しさ〉の高いものを示す。

図一2-A 銀行建築に関する分類結果 
度構成法の一つであり，入力デー夕は個人ごとに，(表 -1）の実験によって算定した 20 の類似性行列である。 なお，安定した解を得るために，単相二元の多次元尺度 構成法であるKYST $2 \mathrm{~A}^{\text {घ5) }}$ の解を初期座標として使用 した。布置の座標は各軸に対して平均値が 0 , 分散が 1 になるように標準化されている。

\section{6-1 実験 A・銀行建築についての分䅡軸}

多次元尺度構成法による分析の結果，5軸の分類軸が 得られた。これらの 5 軸の中で, $I-\mathbb{N}$ 軸平面 (図一2-A) は, クラスター分析における最初の大分類に対応してい る。I 軸は＜建物壁面の色彩〉を示し，正の方向に白色 系, 負の方向に茶色系を示すと解釈できるぜ丶。また $\mathrm{N}$ 軸はく建物壁面のガラス量〉を示し，負の方向にガラス 量が大きく，カーテンウォールの壁面となっている。I
一 $\mathbb{N}$ 軸平面は, 白色系の壁面, 茶色系の壁面, カーテン ウォールの壁面の 3 分類を示しているものと解啋でき る。

なお， I一V 軸平面は，写真事例との対照を可能とす るため写真番号の布置を示したものを併置している。

II一正軸平面（図一-2-A）は，II軸の正の方向に建物 のくファサードの凹凸性 > , 四軸の正の方向に<出入口 の明示性>を示すものと解勫される。<出入口の明示 性〉は建物が角地に立地し, 出入口が建物の出隅部分に 設けられている場合，最大になるものと思われる。

なお，I一IV軸平面による分頑との関係を見ると，II 軸の負の方向くファサードの凹凸性・低〉に，<建物壁 面のガラス量・大 $>\otimes \mid$ 国多く分布している。 このことから，II 軸と N 軸との間にはかなりの相関があ

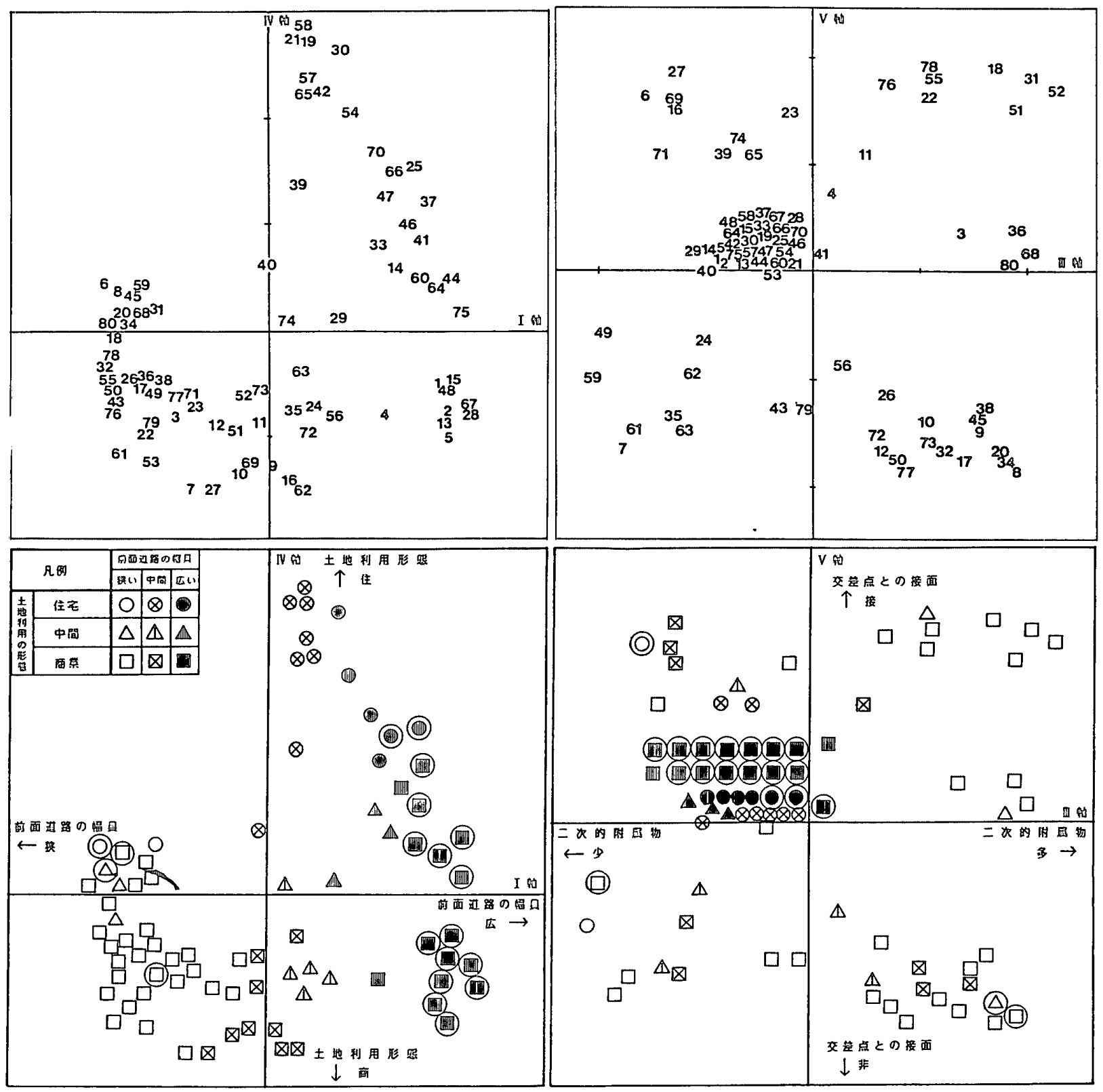

※ 図中の大きなல்印はく街並の密度〉の高いものを示す。

图一2-B 周辺街並に関する分穎結果 
るものと予想される。〔7一（８）〕および（表一5）参照

$\mathrm{V}$ 軸の負の方向に，〈建物の新しさ〉を示すものと解 釈できる。この新しさとは，建物が文字どおり新しいと いう意味と，建物のデザインの斬新性という評価的側面 が含まれているものと推定される。新しいと判断された 上位 20 の事例を上記の 2 つの平面上に大きな○印で示 している。

$\mathrm{I}$ 一 $\mathrm{N}$ 軸平面で見ると, 新しいと判断された事例が, 白色系の壁からカーテンウォール系にかけて分布してい る。このことから, 今回の実験サンプルで見る限り, 新 しい銀行建築の傾向として, 白色系の壁面と, カーテン ウォール系の壁面によって構成されるものが多く, 建築 学科の学生によっても, 新しいと感じられているものと 解釈できる。
II一四軸平面において，特定の傾向は認められない。 6-2 実験 B ・ 周辺街並についての分類軸

多次元尺度構成法による分析の結果，5軸の分類軸が 得られた。これらの 5 軸の中で $\mathrm{I}-\mathrm{I}$ 軸平面 (図一2-B) が，クラスター分析における最初の大分類に対応してい るものと解釈できる。I 軸は正の方向に沿って建物の <前面道路の幅員〉の広さを示し, $\mathrm{IV}$ 軸はく土地利用形 態>が正の方向に商業地域，負の方向に住宅地域の性格 を示している。I一IV軸平面における中央上部に，道路 幅員がやや広く，住宅地域の特性を示す分類があり，右 下方に, 前面道路が最も広く, 商業集積の高い都心部の

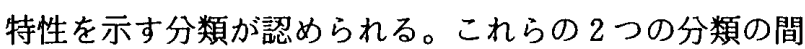
には，前面道路は広いが，商業集積の少ない街並が分布 し，その中間的性格を示している。

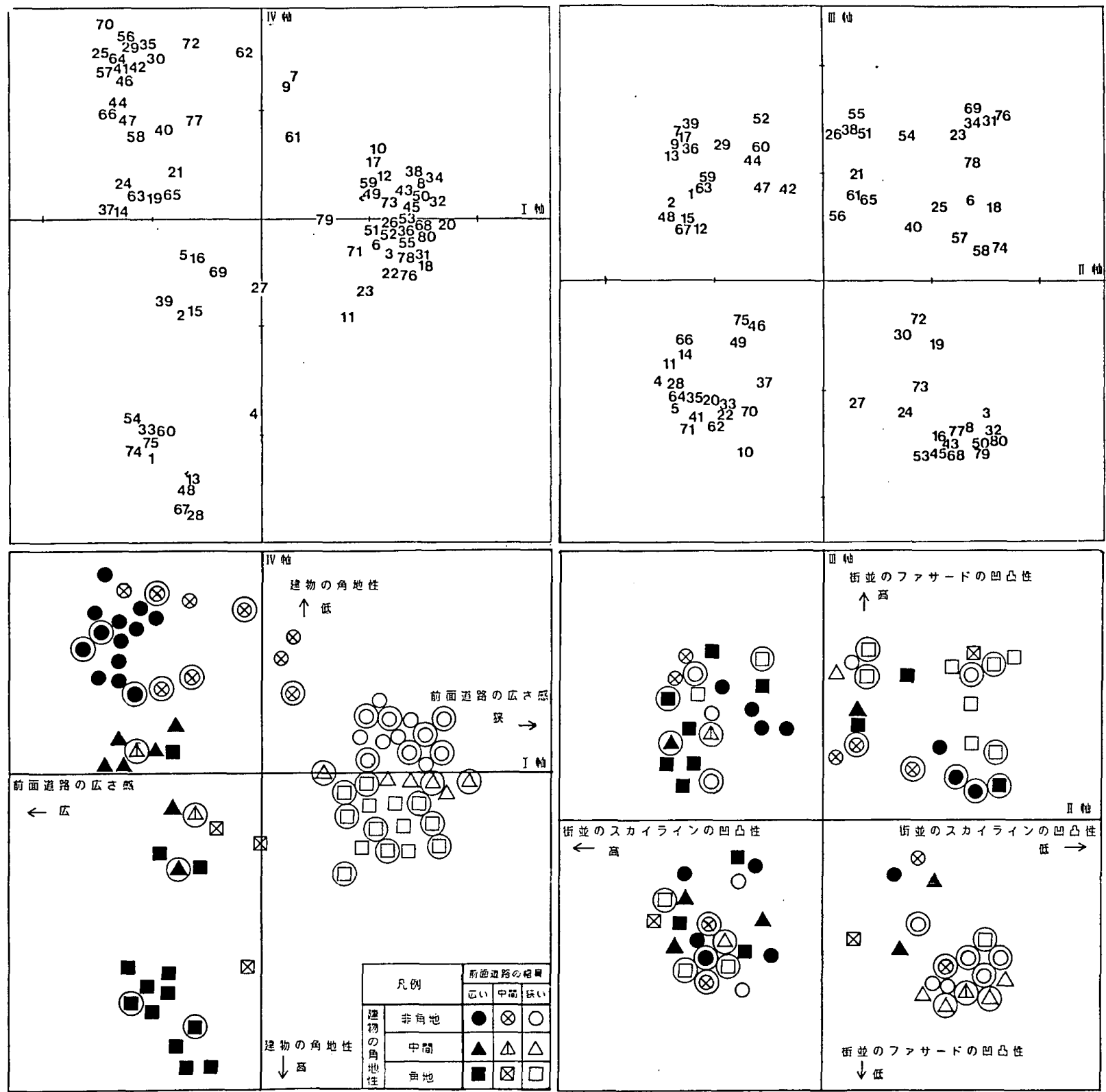

※ 図中の大きな○印はく建物と街並の連続性〉の高いものを示す。

図一2-C 銀行建築と周辺街並の関係性に関する分類結果 
また，平面の左下部に，前面道路が最も狭く，商業集 積の高い街並,すなわち, 低層高密の近隣商店街の特性 が示されている。平面中央の下半部は道路幅員が中間的 な商業集積を示す部分であり，都心部の商業空間と近隣 商店街との間の中間的な性格を示している。以上のよう に，I一IV軸平面上にクラスター分析によって示された 大分類の特性を読み取ることができる。

なお，I-IV軸平面は，写真事例との対照を可能とす るため写真番号の布置を示したものを併置している。

III-V軸平面におけるIII軸は，その正の方向に街並を 構成するく二次的附属物 >が多く，V軸はその正の方向 に，建物がく交差点との接面〉の有無を示すものと解釈 できる。しかし，このIII-V軸平面においては, 都心部 商業地域や住宅地区の事例はすべて，平面の中心部にき

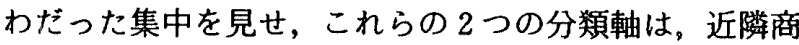
店街をさらに細分するためにのみ適用されたものである ことが推定される。

その理由として,都心部や住宅地域の事例においては, 看板の多少についてはほとんどバラッキがなく，分類の 対象とはならないことが考えられ，交差点に接面するか 否かについては，都心部においてはほとんだすべての事 例が交差点に面し，住宅地については周辺に空地が多い ため, 周辺の街並と交差点の有無とは関係が薄いと知覚 されたものと考えられる。

II 朝は正の方向に<街並の密度〉を示すものと解釈で きる。この密度とは, 周辺街並が全体として十分に整備 され，一つのまとまりとして感じられるという意味であ る密度の上位 20 の事例を 2 つの平面上に大きな丸印で 示している。

$\mathrm{I}$ - $\mathrm{V}$ 軸平面において, 密度の高い街並は，道路幅員 の最も広い部分に多く分布しているが，商業地域と住宅 地域に関しては，その両者にまたがっている。

III-V軸平面においては，平面中央部の道路蝠員の広 い部分にその多くが重なっている。周辺が近陊商店街と 思われる領域には，わずかに 4 例を数えるのみである。

6-3 実験 C・銀行建築と周辺街並との関係について の分類軸

実験Cは銀行建築と周辺街並との関係について多次元 尺度構成法に上る分析の結果, 5 軸の分穎軸が得られた。

I 軸は<前面道路の広さ感>と解勫され，負の方向に 広い。しかし，実験 Bの I 軸が物理的広さであるのに対 し，本軸は，建物と街並との相対的な広さとして分䫛さ れいるものと解䣋される。このことは都心部の高層どル の事例が，や、狭い方に，あるいは，郊外住宅地が広い 方に布置されていることから解釈したものである。また N 軸は，建物の立地条件の<角地性>が，正の方向に角 地，負の方向に非角地が布置されている。したがって， I一 $\mathrm{V}$ 軸平面は，道路幅員と角地性によって分類したも
のであるが，道路幅員が広い分類（I 軸の負の方向）で は角地性に対して強い広がりを示しているのに対して道 路幅員の狭い分類（I 軸の正の方向）では，I 軸の周辺 の狭い部分に集中して分布している。このことは，道路 蝠員が狭い場合には，建物の角地性がそれだけ知覚され 難く, 交差点の手前の街並と連続して知覚されやすいこ とを示している。事実，写真の撮影もそういう構図にな りやすい。一方, 前面道路の幅員が広い場合は角地にあっ て,交差する街並の両者を強く結びつけることにより(そ の場合, 出入口が隅切り部分に位置する場合が多い), その角地性が強く知覚されるものと思われる。

なお， I- $\mathbb{V}$ 平面は, 写真事例との対照を可能とする ため写真番号の布置を示したものを併置している。

II 軸はくスカイラインの凹凸性〉の高い事例が，負の 方向に布置され，回朝は街並のくファサードの凹凸性 $>$ が高い事例が正の方向に布置されている。したがって, II一III軸平面の左上部に最も凹凸性の高い街並, 右下部 に凹凸性の低い街並が布置されているものと解积でき る。しかし，銀行自体のファサードがいかにフラットで あっても，街並との関係に山凸性がある場合，(例えば， 壁面後退などで)，凹凸性の高い方に分熲され実験 Aの II 軸とは異なることに留意する必要がある。

なお， I- $\mathrm{N}$ 軸平面による分類との関係を見ると，II 朝の負の方向＜街並のスカイラインの凹凸性・高〉に

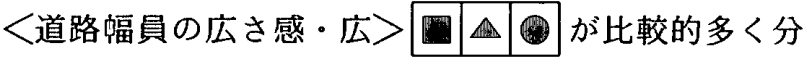
布している。このことから，C I 軸と C II 軸との間には かなりの相関があるものと予想される。（表一5）参照

V軸は＜建物之街並の連続性〉によって分類され，負 の方向に<連続性>が高いものと解积することができ る。この<建物と街並の連続性〉とは, 実験 Cにおけ る各種の分類作業の中で, 最も総合的な基準による分類 として行われたものを推定される。これらのく連続性〉 が高いと分類された 32 事例を，I-IV 軸， II-III 軸平 面において，大きなO印によって示している。I－IN軸 においては, 前面道路が広く, 角地性の高い第 3 象限に 非常に少なく，IIーIII軸においては，スカイラインの凹 凸性の低い方向にや、多いことが認められる。

\section{7. 物的属泾の相関関係}

（表一5）は，実験 A，B，Cにおいて抽出された 5 軸 づつ, 合計 15 軸の分䭭軸の相関係数表である。この表 加実験 A，B，C の区別なく，分穎軸の相互関係につ いて考察することが可能となり, 相関係数 0.400 以上の 組み合わせについての考察は次のとおりである。

（1）実験 B の I 軸〈前面道路の㽬員〉（以下 B I 軸と胃す) と C I 軸<前面道路の広さ感〉との相関係 数が表中最も高い $(0.857)$ 。

（2）続いて B II 軸<二次的附属物>と C II 軸<前 面道路の広さ感 $>$ が高い $(0.627)$ が, このここは, 道 
表一5 分類軸の相関係数マトリックス

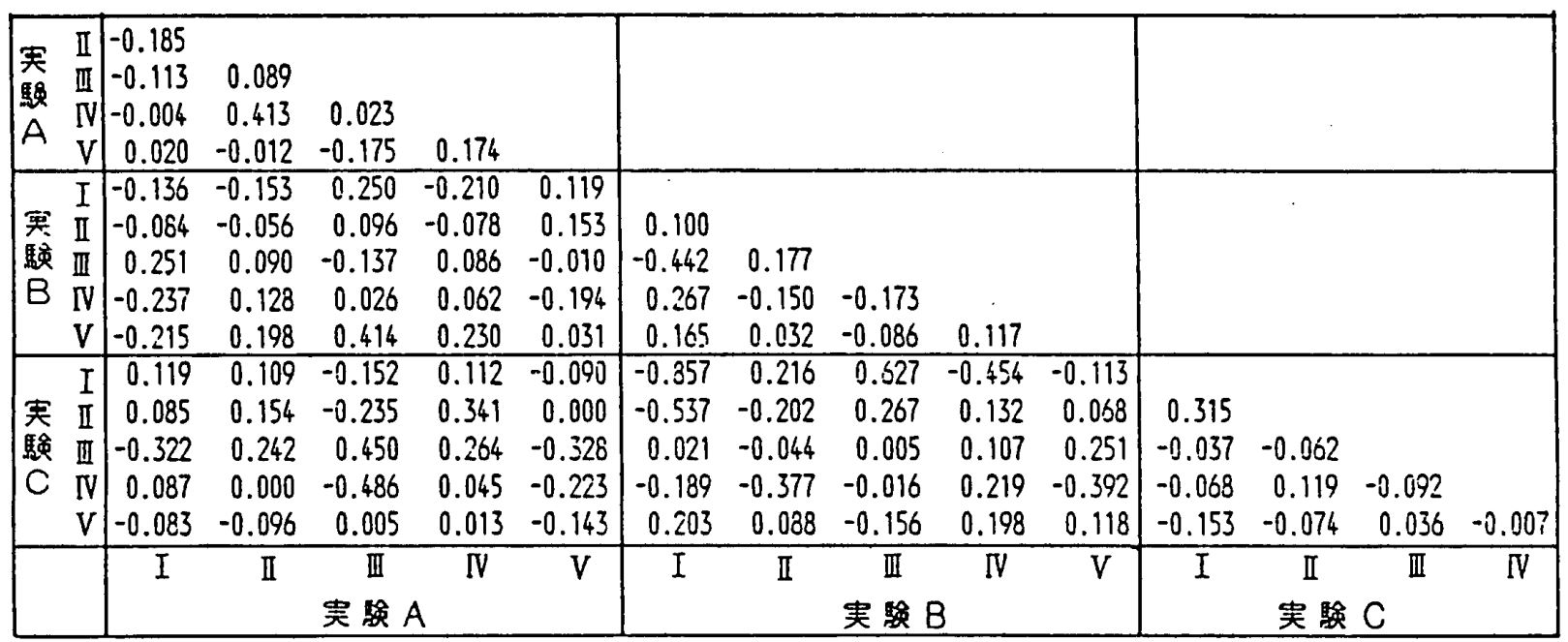

路幅員の狭い近隣商店街において，看板そ.の他の附属物 が多いことを示すものと解釈できる。

(3) B I 軸<前面道路の幅員 > X C II 軸くスカイラ インの凹凸性 $>(0.537)$ は，道路幅員の広い場合に，特 に都心部においてスカイラインの凹凸性が高い傾向を示 しているものと解釈できる。

（4） A III 軸<出入口の明示性 $>\times C \mathrm{C}$ 軸 $<$ 角地性 $>$ (0.486) は, 出入口の明示性が，角地の隅切部分に出入 口が設置されいる場合に高くなる傾向があると解釈でき る。類似の組み合わせとして A III軸 $\times$ B V 軸く交差点の 有無 $>(0.414)$ がある。ここで留意すべきことは，CIV 軸〈角地性〉 $\times \mathrm{BV}$ 軸〈交差点との接面〉(0.392) は, その性格がかなり異なり，BV軸は近隣商店街のような 狭い街路における街並に対してのみ適用された分類軸で あるため，〈角地性〉との相関が低くなったものと解釈 できよう。

（5） B IV 軸<土地利用 $>\times C$ I 軸 <前面道路の広さ 感 $>(0.454)$ は, 商業地域（都心部および近隣商店街） では, 前面道路の広さ感が小さく, 住宅地域の性格が強 い程，広さ感が大きくなる傾向を示している。

（6） A III 軸<出入口の明示性 $>\times C$ III 軸<街並の ファサードの凹凸性>(0.450) は街並に対する銀行建築 のファサードの山凸性が高い場合, 建築の出入口の明示 性が高い傾向を示している。

（7） B I 軸 <前面道路の幅員 $>\times$ B III 軸 $<$ 二次的附 属物>(0.442) は, 道路幅員の狭い近隣商店街において, 二次的附属物が顕著になる傾向を反映したものと考えら れる。

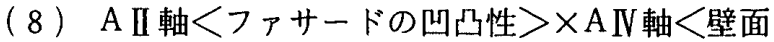
のガラス量 $>(0.413)$ は, 銀行建築において, 壁面のガ ラス量が大きくなり，カーテンウォールによるファサー ドの構成がされる場合, 凹凸性は低くなる傾向を示すも のと考えられる。
（9）以上 9 個の組み合わせのうち，6 個は, 実験 C との組み合わせであるが, 実験 $\mathrm{C}$ ，実験 $\mathrm{A}$ と実験 $\mathrm{B}$ と の関係性の抽出を目的としたものであるため，当然の現 象と思われる。

\section{まとめ}

東京城南部の私鉄各沿線に存在する銀行建築と, その 周辺街並の関係性に関する分析を行うため, 神奈川大学 建築学科学生 20 名を被験者とし，80 枚のカラー写真を 用いて，4段階にわたる分類作業を行った。得られた 20 とおりの類似性行列を入力とする多次元尺度構成法 SINDSCAL によって分析した結果，以下のような知見 が得られた。

（1）実験 Aにおいて銀行建築自体を分類するための 物的属性の分類軸として以下の 5 軸が抽出された。

A I 建物壁面の色彩 (白一茶)

A II 建物ファサードの凹凸性（高一低）

A III 建物出入口の明示性（高一低）

AIV 建物壁面のガラス量（少一多）

AV 建物の新しさ（古一新）

（2）実験 Bにおいて，銀行建築の周辺街並を分類す るための物的属性の分類軸として以下の 5 軸が抽出され た。

B I 前面道路の幅員（広一狭）

B II 街並の密度 (高一低)

B III 二次的附属物 (多一少)

BIV 土地利用形態（住一商）

BV 交差点との接面（接一非）

（3）実験 Cにおいて, 銀行建築と周辺街並との関係 性を分類すための物的属性の分類軸として, 以下の 5 軸 が抽出された。

C I 前面道路の広さ感じ（狭一広）

C II 街並のスカイラインの凹凸性（低一高）

CIII 街並のファサードの凹凸性（高一低） 
CIV 建物の角地性（低一高）

CV 建物と街並の連続性（高一低）

（4）これら 15 の分類軸の中で，AV，B II，CVの 3 軸は, 被験者によって何らかの評価的判断をされたも のと思われ，特に高く評価された事例については，他の 分㴿軸による平面の上に布置し，その関連性を考察した。

（5）以上の合計 15 の分頪軸の相関係数マトリック スから，抽出された分穎軸間の相互関係を，実験の種別 にもかかわらず考察できる。

これらの相関係数の中で, 0.700 以上の高いもの 1 個, 0.400〜0.700のやや高いもの8 個が認められたが，そ れらの理由について考察された。合計 9 個数の組み合わ せの中で，実験 Cが関係する組み合わせが 6 個であった が, 実験 Cが, 実験 $\mathrm{A}$ と実験 $\mathrm{B}$ との関連づけを行おうと する実験であることから当然の現象であるものと思われ る。

（6）合計 15 の分頪軸とその相互関係に関する考察 をより正確に確認するために，次編において，80枚の カラー写真に対して, 本実験と同じ被験者による SD 法 分斩を行い，本実験結果と評価構造との関係を報告する 予定である。

注

1）銀行建築に対する知覚構造を対象とした研究は少ないが， [文献 14]においては, 角地に建つ銀行のファサードに 対する評価構造が SD 法によって分析されている。しか し, 銀行のファサードを単独で倸価したものであり, 周 辺の街並との関係性は問われていない。

街並や街路景観の知賞構造や俨価構造を対象とする既 往の主要な研究事例として [文献 5 13] がある。これ らの中で街並や街路景観において知覚の対象となる物理 的な構成要素とその属性を実験的に抽出しようとする研 究は [文献 6,11，13] である。もちろん，これらの研 究は第 2 段階において評価構造との関連において分析さ れている。本研究もこの䉇晤に入る。[文献 6] は街路景 観をカラースライドに撮り，被験者に対する瞬間視実験 を行うものである。[文献 11，13] は対象を写したカラー 写真を被匰者に提示し，分䭭作業をさせることにより， 対象間の類似性行列を得, 多次元尺度構成法によって分 類軸を得る方法である。本研究はこの方法に依っている。

2）本論文で採用した段階別分類の方法は，Ward (1977) [文 献 18], Russell (1980) [文献 19], 宮本, 他 (1986) [文 献 13]によって使用されている。この分穎作業について, Ward は次のように述べている。

「の分穎手続は被験者にとって容易で早くできる作業 である。しかも，一対比較による手続と同じ位有効な類 似度が得られる。」

3）アメリカのベル研究所で配布されているクラスター分析 のブログラムで, 1967 年に Johnson, S.C.によって作 成された。

4）アメリカのベル研究所で配布されている多次元尺度構成 法のブログラムで，1975 年に Carroll，J.D.および
Pruzansky，S．によって作成された。

多次元尺度構成法とは，Kruskal，J. B. \& Wish，M. [文献 16] に上れば，「さまざまな対象間の穎似性を入力 データとする手法を指す。……結果から得られるのは, 点の幾何学布置からなる空間的表現である。布置の点が それぞれの対象を表し，全体としてデー一タの中に潜在 している構造を表す」(P.1) さらに頪似性の算定方法と して「刺激数がかなり多い場合（50から100くらいまで） でも簡単に使える方法として，穎似性に応してて被跧者に 刺激を分穎してもらう方法がある」(P.4)としている。

5）アメリカのベル研究所で配布されている多次元尺度構成 法のプログラムで, 1977 年に Kruskal, Young, Seery に よって作成された。

6）分䫛軸の解橎の方法は，表一2, 表一3によってあらかじ めまとめられた被験者による分頢理由を参照しながら，2 つの朝の平面上の写真事例の布置を観察して行うもので ある。この钼察方法の原則は次のように述べられている。

「まず布置の周辺部にある番号に注目し，その番号とそ の周りにある番号の共通点は何かと問いかけてみる。次 に，その番号と反対側にある番号の相違点は何かと考え てみる。」Kruskal, Wish (1978) [文献 16] P.8,

なお，以上の引用部分は，モールス信号の分穎朝の解 釈方法について述べている部分であるため,引用文のく番 号〉は原文ではく信号〉となっいる。

\section{参桨立能}

1) 志水英樹, 福井 通：中心地区空間におけるイメージの 满造（その1）, 日本建築学会諭文報告集No. 229, 1975.3

2) 志水英樹, 福井 通：中心地区空間におけるイメージの 構造（その2）, 日本建築学会論文報告集No. 236, 1975.10

3）志水英澍, 福井 通：中心地区空間におけるイメージの 構造（その3）一業種イメージの属性別研究一, 日本建 築学会諭文報告集 No. $244,1976.6$

4）志水英樹, 福井 通: 中心地区空間におけるイメージの 構造（その4）ーレジビリティとアンビギュイティに対 する情報理論的考察一, 日本建築学会論文報告集 No. 263， 1978. 1

5）渡辺貫介, 大下 茂：中心商業地における街路景観の改 善方法の研究, 日本都市計画学会学術研究発表会論文集 No. $17,1982.11$

6）奥 俊信：瞬間視実験に基づく街路景観構成要素の分析 一街路景観の視覚特性ならびに心理的効果に関する実験 的研究 第 1 報一, 日本建築学会論文報告集 No. 321 , 1982.11

7）铅越 徹, 穞田 洋: 街路空間における空間意識の分析 (心理量分析) 一街路空間の研究 (その1)一, 日本建築 学会論文報告集 No. $327,1983.5$

8）奥 俊信 : 街路景䔘構成要素の景観評価への影䈉につい て一街路景観の視覚特性ならびに心理的効界に関する実 跧的研究 第 2 報一，日本建築学会計画系論文報告集 No. $351,1985.5$

9）奥谷 㟓：心理的側面からみた商業地域の空間構成, 都 市計画 No. 138，1985.12

10）平手小太郎, 安岡正人：街路澍のある都市街路景観の評 価に関する研究一白黒合成スライド写真による実験的研 
究，日本建築学会計画系論文報告集 No. $362,1986.4$

11）谷口汎邦, 谷津憲司, 宮本文人, 山口勝己：大都市にお いて学校施設が構成する街並の物的属性について, 日本 建築学会 地域施設計画研究シンポジウムNo.4, 1986.5

12）船越 徹, 積田 洋: 街路空間における空間構成要素の 分析 (物理的分析)一街路空間の研究 (その 2$)$ 一, 日本 建築学会計画系論文報告集 No. 364, 1986.6

13）宮本文人, 谷口汎邦 山口勝己：大学キャンパスにおい て 2 棟の建物が構成する外部空間の物的属性について一 大学キャンパスにおける建築外部空間の構成計画に関す る研究 (その3)一, 日本建築学会計画系論文報告集 No. $364,1986.6$

14）高倉正美, 平手小太郎, 鎌田元康, 安岡正人：スライド
実験による角地に建つ銀行のファサードの評価に関する 研究, 日本建築学会大会学術講演梗概集 No. 4192, 1984. 10

15） CDI 編：コミュニティバンクの空間計画一その理論と実 践一, 鹿島出版会 1983

16） J. B. クラスカル，M. ウィッシュ：多次元尺度法, 高根 芳雄訳 朝會書店 1980

17）阁藤筧幸：多次元尺度構成法 朝倉書店 1980

18) WARD, L. A. : Multidimensional scaling of the molar physical environment, The Journal of Multivariate Behavioral Research, 1977.

19) Russell, J. A. : A circumplex model of affect, Journal of Personality and Social Psychology, 1980.

\section{SYNOPSIS}

UDC : $711.4 .01: 72.011: 159: 725.24$

\section{THE STUDY ON THE PHYSICAL ATTRIBUTES PERCEIVED OF THE TOWNSCAPE COMPOSED WITH THE BANK BUILDING}

by Dr. HIDEKI SHIMIZU, Professor of Kanagawa University, Dr. HIROKUNI TANIGUCHI, Professor of Tokyo Institute of Technology, and Dr, FUMIHITO MIYAMOTO, Associate Professor of Tokyo Institute of Technology, Members of A.I. J

The physical attributes perceived of the townscape composed with the bank building were studied through the sorting experiments of 80 color photographs by 20 architectural students.

The experiments were proceeded in 3 areas. ( 1 ) on the bank building itself, ( 2 ) on it's surroundings, ( 3 ) on the relationship between the bank building and it's surroundings. The similarity matrix which was constructed from this sorting process was imput to the multidimensional scaling analysis "SINDSCAL". 5 sorting dimensions from each experiment were extracted and interpretated for the physical attributes. 